\title{
Targeting oncogenes in advanced melanoma
}

\author{
GA McArthur \\ From Familial Aspects of Cancer 2011 Research and Practice: A combined meeting of kConFab, Australian \\ Breast Cancer Family Study, Australian Colorectal Cancer Family Study, Australian Ovarian Cancer Study, \\ Family Cancer Clinics of Australia and New Zealand and kConFab \\ Kingscliff, Australia. 23-26 August 2011
}

The ability to target oncogenes in malignancies such as CML, GIST, APML and ERBB2-positive breast cancer has revolutionized the management of those diseases. Interesting over $70 \%$ of melanomas contain genomic amplification or mutations in one of the oncogenes BRAF, NRAS, KIT, CCND1 or CDK4 that may induce an oncogene addicted state. Inhibition of BRAF with Vemurafenib or GSK2118436 in BRAF-mutant melanoma have shown responses in over $50 \%$ of patients with advanced disease and in the case of Vemurafenib striking improvements in survival compared to DTIC. These data suggest that there are therapeutically targetable oncogenes in melanoma. However emergence of resistance is common. A number of mechanisms of resistance have been identified including reactivation of the RAS/RAF/MEK/ERK pathway. Current focus is the development of combination strategies including the addition of MEK-inhibitors to BRAF-inhibitors and the combining targeted agents with immunological agents such as Ipilimumab. Together these data indicate that targeting oncogenes in melanoma offers significant therapeutic opportunities in one of the most challenging of human malignancies for systemic therapy.

Submit your next manuscript to BioMed Central and take full advantage of:

- Convenient online submission

- Thorough peer review

- No space constraints or color figure charges

- Immediate publication on acceptance

- Inclusion in PubMed, CAS, Scopus and Google Scholar

- Research which is freely available for redistribution

Submit your manuscript at www.biomedcentral.com/submit
() Biomed Central

\section{BioMed Central}

(c) 2012 McArthur; licensee BioMed Central Ltd. This is an Open Access article distributed under the terms of the Creative Commons Attribution License (http://creativecommons.org/licenses/by/2.0), which permits unrestricted use, distribution, and reproduction in any medium, provided the original work is properly cited. 